\title{
Russian Literature and Russian Music
}

\section{Montagu-Nathan}

To cite this article: M. Montagu-Nathan (1914) Russian Literature and Russian Music, Proceedings of the Musical Association, 41:1, 113-134, DOI: 10.1093/jrma/41.1.113

To link to this article: http://dx.doi.org/10.1093/jrma/41.1.113

曲 Published online: 28 Jan 2009.

6 Submit your article to this journal 중

Џll Article views: 10

Q View related articles $\sqsubset$ 
April 20, 1915.

CHARLES MAClEAN, EsQ., M.A., Mus.Doc.,

ViCE-PRESIDENT,

IN THE Chair.

\section{RUSSIAN LITERATURE AND RUSSIAN MUSIC.}

By M. Montagu-Nathan.

M. Camille Bellaigue, the well-known French critic, in an essay on Russian Music, expresses his opinion that the music of Russia is composed of two elements : the national element and the popular, and he then proceeds to quote Turgenef's dictum with reference to the attention that ought, in the great author's opinion, to be paid to the national element in Literature.

Russian Literature and Russian Music, as a study of their respective histories will show, have more than this point in common. They are both an expression of nationalism, they have both undergone a process of emancipation, and they are both what one writer has termed, in relation to Literature, a protestation against the past.

It is not at all difficult to provide an illustration of what is meant by the national element in Russian Literature. If we examine the works of the best-known literary men of Russia, we shall find ample evidence of their preoccupation with national matters. They have devoted themselves to History, Folklore, to the study of contemporary manners among the official, merchant, and peasant classes, and to that of the national character as a whole. They have also left some wonderful descriptions of the Land itself.

Pushkin's "Boris Godounof" is an example of historical literature fortunately well known to us. His story "The Captain's Daughter" concerns an episode in Pugachof's rebellion. The same author's "Evgenie Oniegin" portrays two men and a 
woman who are considered typically Russian. He has given us among his essays in the style of Folklore "Russalka," picturing therein the Russian legendary water-nymph, "The Legend of Tsar Saltan," and another popular tale in verse called "The Doom of Oleg." Lermontof, as becomes a soldier, has described the conditions both of Russian contemporary and of remoter military life. Pechorin, his "Modem Hero," is in part autobiographical, and is based on his own behaviour and experience while quartered in the Caucasus. "The Oprichnik" and "The Story of the Merchant Kalashnikof" tell us of the evil works wrought by the bodyguard of Ivan the Terrible. Gogol's "Evenings on a Farm at Dikanka" and his "Mirgorod" contain the elenents of Folklore and of village life in his native Ukrain. The first-mentioned volume is largely composed of stories of a supernatural character; it includes "The Fair at Sorotchinsk," which is a study of peasant life. His "Matchmaker" takes us into the town. Turgenef had a good deal to say about Russian reformative movements, and incurred some blame for his satirical treatment of the subject. The works of Tolstoi are so well known as to obviate any necessity of referring to their national and popular content. By virtue of his "War and Peace" he also is able to claim the rôle of modern historian. Dostoievsky's novels may be quoted with a special appropriateness since their general ethical tendency and their repudiation of the doctrine of Might reflect quite faithfully the Russian national character.

The names of several of the works I have mentioned under the heading of nationalistic Literature are recognisable as the titles of musical masterpieces. This is not a coincidence. The most famous Russian operas are those which are based on Russian history, Russian folklore and Russian life as expounded by national poets. The majority of the operas on Russian subjects best known to us derive their literary origin from that ardent nationalist Pushkin, whom Mr. Baring dubs the Mozart of Russian literature. Glinka's "Russlan and Ludmilla," Dargomijsky's "Russalka," Moussorgsky's "Boris Godounof," Tchaikovsky's "Evgenie Oniegin" and "Queen of Spades," Cui's "Prisoner of the Caucasus " and "Captain's Daughter," Rimsky. Korsakof's "Tsar Saltan" and "Golden Cockerel," and Napravnik's "Doubrovsky" are all from the same source. These are safely classified under the category of expressions of nationalism. But Pushkin, while perhaps the greatest, is not the only Russian poet favoured by musicians, and historical works which, like Glinka's "Life for the Tsar," give a view of various periods of Russian history, are legion. Most of them come within the scope of this Paper since they were Literature before they came to be associated with Music. 
The earliest historical period touched upon by Russian opera appears to be that of Askold. Verstovsky's third opera, "Askold's Tomb," therefore gets the honour of first place in our list. Askold was a follower of Rurik, the Scandinavian founder of the Russian State in the ninth century. He left his chief and with his comrade in arms, Dir, set out to seek his fortune. Following the bank of the Dnieper they came to Kief and there established themselves as Princes, remaining until trapped and executed by Rurik's son Igor.

A rather large space of time elapses before we reach the next example of History treated musically. Ivan II.'s son Dmitri Donskoi, the hero of Rubinstein's opera, beat the Tatar Khan Mamai at the battle of Kulikova Pole (Woodcock's Field) on September 8 th, 1380. The battlefield is situated on the Don, hence Dmitri's soubriquet.

Making a leap of a century and a half we now arrive on more familiar ground, and contemplate the sinister figure of Ivan the Terrible, whom Shalyapin's performance in Rimsky-Korsakof's opera helps us to remember. He is also to be found, or at least referred to, in two other operas by the same composer. The first opera of Kazachenko, born 1858, is called "Prince Serebryany," and is based on the historical novel by Alexis Tolstoi, whose work is said to rival that of Walter Scott. Serebryany was the champion of the nobility against the tyrannies of Ivan.

It is permissible to pass lightly over the historical interest of "Boris Godounof." Sir Joseph Beecham and his company have seen to that. We must refer to another work of Alexis Tolstoi. His dramatic trilogy, "The death of Ivan the Terrible," "Tsar Feodor " and "Tsar Boris," covers the period we are now leaving. 'The first two parts have been set to music by Grechaninof, and the third by Kalinnikof. Remembering the story of the False Dmitri, to whom Moussorgsky introduced us, we shall be the more interested in the Pretender who followed him. The widow of Grigory Otrepief, the man we saw at Drury Lane as monk and monarch, leaving nothing undone in her efforts to secure a throne, became the wife of this second Dmitri, but they were not allowed to remain long at the head of affairs. The lady, it should be explained, was the lover of the Dmitri whom we saw escape through the window of the Inn, but owing to the excision of a whole Act we were denied her acquaintance. The second Dmitri was known as the Robber of Toushino (the name of the place from whence he came), and is the central figure in Blaramberg's opera "Toushintsi."

All this period since the death of Ivan the Terrible, during which Russia was without a properly appointed ruler, was known as "The Time of Trouble." 
With a view to putting an end to the unrest, it was decided to elect a member of a noble family as Tsar, and young Michael Romanof, whose family was related to Ivan the Terrible, was chosen as occupant of the throne. The Poles, always a source of political difficulties, did their best to upset this plan and plotted to kidnap the newly-chosen monarch. This plot is supposed to have been foiled by the heroic exploit of Ivan Soussanin, who is credited with having led the Polish forces into an impenetrable forest. Falling a willing victim to their vengeance, he gave his life for the Tsar, and provided the librettos of two operas by Cavos and Glinka, respectively.

During the reign of Michael's son Alexis, which began on his father's death in 1645 , the Cossacks, who were under Polish rule, became dissatisfied with their treatment, and, revolting, took an oath of allegiance to Alexis in 1653 . But Cossack promises seem in those days to have been made with a very light heart, and a few years later, in 1667 , Stenka Razin began his campaign of plunder, which ended with his execution at Moscow in 1671 . A romantic episode in his career has been used by Glazounof in his Symphonic Poem which bears the Robber's name.

Alexis married twice. By his first wife there were two children, Ivan and Sophia. Peter the Great was the child of his second wife. Ivan, the rightful heir, was of weak intellect. Sophia, his sister, was bent on getting power, and organized a revolt which was suppressed after three days. The half-brothers, Ivan and Peter, were proclaimed joint Tsars, and Sophia was appointed Regent. She made the very most of her position and divided her favour between three Princes: Khovansky, Miloslavsky, and Galitsin. The Streltsian revolt was headed by Khovansky, and was called "Khovantschina," the title of Moussorgsky's music-drama. As soon as Peter was old enough to get the reins of government into his hands he banished Galitsin, and Shaklovity, who had been entrusted with the assassination of Khovansky, was beheaded. Sophia be placed in a monastery. A contemporary writer describes Sophia as having a monstrous body, a head to match, and finishes his detailed corporeal catalogue with the conjecture that she must have been at least forty years of age. I mention these physical abnormalities as they may account, perhaps, for her non-appearance in Moussorgsky's opera. She did appear, by the way, in an earlier version, which was not published. Galitsin was kept from our view at Drury Lane by the omission of the only two scenes in which he figures.

In 1700 began the war with Sweden. Peter desired a port on the Baltic, and with this end in view made a secret alliance with the Danes and Poles. The latter were to invade Livonia, and Peter reckoned on seizing Ingria and Carelia. Charles XII. 
upset these plans for a time. He beat first the Danes and then the Russians, but taking insufticient advantage of his victories, eventually saw Peter established at Schlüsselburg. At this moment the foundations of Petrograd were laid. Peter now went to the assistance of Augustus of Poland, but Charles had already gained a victory in that quarter, and determining this time to pursue his advantage, announced his intention of dictating his conditions of peace from Moscow itself. He began his march, and things began to look serious for Peter, particularly when the Cossacks went over to the enemy with the object of ridding themselves of the domination of Little Russia. Mazeppa, the Cossack leader, was denounced by the general Kochoubey, with whose daughter, Maria, he was in love. Subsequently Charles was decisively defeated at Poltava in 1709 . This battle is celebrated by Tchaikovsky in his opera "Mazeppa." It is worthy of mention that a descendant of Peter's leading general, Sheremetief, is now associated with Russian musical enterprises.

The succeeding period which covers the reigns of Anne and Elizabeth, though favourable to musical progress, does not appear to have provided any literary subject to inspire Russian musicians.

The last two historical episodes in our chronicle both occurred in the reign of Catherine II. The first of these concerns Pugachof.

Peter the Great left no heir. His rebellious son Alexis is supposed to have been murdered at his father's instigation. Peter's wife, Catherine I., succeeded him, but reigned only for two years. In accordance with Peter's ukase of 1721, she nominated her own successor, and her choice fell upon the son of Alexis, who thus became Peter II. He died in 1730 after an uneventful reign. After him came Anne, the daughter of Peter the Great's half-witted brother. She occupied the throne for the next seven years, during which Russian Literature took a sudden leap forward. She, like Catherine I., duly noninated a successor. Ivan the new Emperor was a grandson of Anne's sister. He was but an infant, and Elizabeth, Peter the Great's surviving daughter, succeeded in getting rid of him. Her reign, like that of Anne, was artistically fruitful. The Academy of Fine Arts and the first Russian Theatre were both inaugurated at this time. Elizabeth died in 1761. Her appointed successor was Peter the Great's grandson. Peter III. had married some twenty years previously the German lady who became Catherine the Great. He suffered the fate of all weak men in Russian history, and was got rid of. The Northern Semiramis then began her brilliant reign. But just as Boris is supposed to have teen pursued by the results of his crime, so was Catherine. Boris was never free from attacks organiced by false claimants to the 
person of the murdered Dmitri. Catherine had to contend with a very powerful false Peter 11I. in the person of Pugachof, who pretended to have escaped the assassination which was presumed to have closed the career of Peter. Pugachof was joined by Cossacks and Old Believers-the Dișsenters we met in "Khovantschina"-and accumulated such power as seriously to endanger Catherine's throne. Pushkin's story "The Captain's Daughter" relates some of Pugachof's murderous exploits, and is the foundation of Cui's latest opera produced in 1911 at Petrograd.

Towards the end of Catherine's reign, Patyomkin, her favourite, who lost no opportunity of impressing his Queen with a sense of the prosperity of her Empire, organized a huge and dazzling festival which forms the material of an opera by lppolitofIvanof, called "Patyomkin's Feast." Before closing our list we may mention in this connection the Imperial Progress to the Crimea conducted by Patyomkin, who caused to be erected a number of cardboard villages calculated to make a more favourable impression on Catherine than the bare plains of which they were the temporary ornament. This journey is referred to ad nauseam by the old Mayor in Rimsky-Korsakof's "Night in May," who does his utmost to extract every ounce of glory from his comparatively insignificant official connection with the aflair.

I trust that this enumeration of instances of what may be called musico-literary material has not proved wearisome. You will at any rate agree with me that the material just quoted forms a fairly good example of one way in which Music may be nationalised. 'The Russian composer, as we have seen, has wellnigh succeeded in writing a history of Russia in music. It should be remembered too that the works cited are among the greatest in Russian musical history. We may be satisfied therefore that apart from their historical interest they have proved their quality as music. Later on I shall try to show you that the influence of Russian literature-literature that has no definite relation to history - has been by no means small.

I must first illustrate my meaning when suggesting a comparison between the emancipation of Russian literature and that of Russian music.

Just about a hundred and twenty years before Balakiref and Cui began their movement for the formation of a genuinely Russian musical language there was founded, in 1735 (during Anne's reign), a Society of Friends of the Russian language-the literary language, of course. The Society was conducted by Vasili Kirilovich Trediakovsky (1 703-69), the son of a priest, and its proceedings were inaugurated with an address on "The Purity of the Russian Tongue." We are told of Trediakovsky's 
bewilderment when confronted with the official language of Peter the Great's creation, ". . . a second Tower of Babel .... stuffed full with German, Dutch and French words...." and forced by superior orders on the translators of foreign books. In his address Trediakovsky dealt with the necessity of formulating a grammar and an authoritative system of rhetoric and poetry. Some idea as to the extent of the foreign literary invasion of Russia is obtainable from knowledge of the fact that a few years later, when the Empress Elizabeth nominated Trediakovsky professor of Russian elocution at the newly-established Academy, the Committee of the institution - entirely composed of foreigners - showed open resentment at the proposed introduction of a mere native to the Staff.

It is interesting to observe the engaging coincidence that whereas Trediakovsky was on occasion subjected to severe bodily maltreatment by members of the Court of the Empress Annehe once had his face slapped by an enraged Minister-his successor in the task of what is usually called the forging of the Russian literary language was named Lomonossof, which means broken-nose. The coincidence is, to say the least of it, suggestive. That Lomonossof - the son of an Archangel fishermanrecognised the magnitude of his task is quite plainly seen in his own writings on the subject of his mother-tongue. In the preface to his Russian Grammar he regrets that certain Russians have devoted themselves to the study of foreign languages to the neglect of their own. He recalls the dictum of Charles VI. to the effect that one ought to speak Spanish with God, French with one's friends, German with one's enemies, and Italian with women. But had this monarch known Russian, observes Lomonossof, he would most certainly have added that this tongue was a suitable medium in which to address everyone, including of course the Divine Being. He would have found therein, continues our grammarian, the majesty of Spanish, the vivacity of French, the strength of German, the delicacy of Italian, and besides, the wealth and concise picturesqueness of Greek and Latin. The vigorous eloquence of Cicero, the stately gravity of Virgil, the pleasing elegance of Ovid, lose nothing when rendered in Russian. The most delicate ideas of the philosopher, the ever-varying aspects and changes of nature and all the phenomena of the moral system find a facile expression in the language of Russia.

Gogol has not only expressed much the same sentiment, but he has also added a satirical protest against the tendency, still prevalent in his own time, to pay an undue attention to foreign tongues. One of his heroes, asked what quality he most desires in a bride, confesses that in his view a knowledge of French is the most pleasing attribute imaginable. 
That there was still plenty of work to be done after Lomonossof's labours were over may easily be grasped from the following quotation from the Memoirs of Prince Patyomkin, Commanderin-Chief and Court favourite of Catherine the Great. "Although the Russian language," he says, "has not yet attained that degree of perfection which a brilliant genius may impart to it at some future time, yet it is the richest, the most simple and the most picturesque language of modern Europe."

Sir John Bowring, in the preface to a second edition of his volume on Russian poets-published in 1821 -throws a light upon the subject which helps us to obtain a clear idea of the condition of Russian Literature prior to the advent of the hopedfor brilliant genius. "It must not be forgotten," he says, "that this [volume] is a representation of nothing but the unformed, but infant poetical literature of Russia. That literature had its birth but yesterday, and certainly its present strength and beauty give fair hope for to-morrow. In it are elements of improvement, and buds and blossoms of future expectation. They are scattered .... and in due time will ripen, to encourage, to console, and to stimulate myriads and millions. It will then be an interesting task, to compare the maturer charms of Slavonic song with these, its earliest gems."

Lomonossof he calls the Father of Russian Poetry. He did more than any other writer, says the Englishman, to fix the standard of language, and wielded a then uncouth and unformed idiom with singular address and power.

The next effort towards the ordering of this medium was made by Karamsin, the historian, from whose chronicles some of the episodes of Moussorgsky's "Boris Godounof" are derived. Of him we are told that his love of English literature was so remarkable (he made a translation of Julius Cæsar) that the members of the Society of Friends of the Russian Tongue nicknamed him Ramsay - a name bearing a remote enough resemblance to his own, Karamsin. Karamsin, apart from his labours as historian of the Russian Empire, is credited with having to a large extent succeeded in freeing the Russian language from the bondage of classical tradition. What Lomonossof did for poetry Karamsin did for prose.

The work of a man three years his senior is said to have been greatly influenced by him. I refer to Krilof, the writer of Fables. As one of them is, so to say, musical, I propose to recite it to you. I am ignoring the standard prose translations, and give you the poetic version of Mrs. Newmarch ("The Quartet").

It is said that this Fable refers to the foundation, in 1811 , of the Society of Friends of Russian Literature. It had four departments in which positions were allotted rather according to social rank than to literary merit. No one will be surprised after 
bearing this fable to learn that its author was no mean musician; he played the violin, we are assured, as ably as many a virtuoso. He spent some years in the household of Prince Sergius Galitsin, who, like his more famous namesake, interested himself practically in the tonal Art. Another fable having a partly musical subject is that concerning an Ass who prided himself on the strength of his fancied judgment in musical matters, and a Nightingale whom he invited to an audition. It is worthy of mention that César Cui has made musical settings of more than one of Krilof's worksr

The brilliant genius whose advent was foretold by Prince Patyomkin duly arrived in 1799 . His name was Alexander Sergeievich Pushkin, and his first verses were published in 1814 . Of Karamsin it is recorded that he was disinclined to foster a spirit of undiluted nationalism in Russian Literature. "Let us," he said, "be men before being Slavs." But Pushkin lived for a Russian Literature of which the primary function was to be the exposition of the Russian national character and a reflection of the Russian type.

Nothing more succinct has been said on the subject than the opinion to which Dostoievsky committed himself : "If a Russian does not understand Pushkin he forfeits his right to be called a Russian." Gogol, in his "Arabesques" wrote, "Only the man to whom Russia is the fatherland can understand these pictures of Pushkin, saturated as they are with the Russian spirit."

Pronouncements such as these give us good reasons for deciding that it is really from the seed of Nationalism sown by Pushkin that the.modern Russian Literature has sprung. Or, to distribute the credit over a wider field, and to revert at the same time to the popular musical metaphor, it was Pushkin who first played on the instrument prepared so laboriously by his precursors, 'Trediakovsky, Lomonossof and others.

In my History of Russian Music I have quoted a prediction, very similar to that of Patyomkin, made by the Vicomte Melchior de Vogué, author of the French volume entitled "Le Roman Russe" (The Russian Novel). But when this writer opined-in the 'eighties of last century - that only when Russia should beget some serious musicians would her folk-songs come into their own as a prolific source of musical inspiration, he clearly overlooked a very important circumstance, namely, that at this very moment Russia was enjoying a veritable "Golden Age" of national music. Moussorgsky had just died, Balakiref and Rimsky-Korsakof were in the prime of life, and Borodin must have been looking forward to a good many more than the few remaining years apportioned him by Destiny.

I think you will agree with me when I say that the history of the emancipation of Russian national music is in many respects similar to that of Russian literature. 
The initial gropings of Trediakovsky may well be compared with the somewhat ineffectual struggles on the part of the precursors of Glinka to free their native music from the foreign gilded trappings with which it had been so profusely adorned by the alien. But when, in developing this comparison, we arrive at Pushkin we are obliged to confess that the credit of being the first to play on the national musical instrument, over which Glinka never obtained a complete mastery, must be divided among several musical Pushkins. Balakiref, Moussorgsky, Borodin and Rimsky-Korsakof, have united in playing Pushkin to the Trediakof, Lomonossof, and Karamsin of Cavos, Glinka, and Dargomijsky. Each of the four allied composers excelled in his own particular domain. Each played upon the instrument, prepared for him by forerunners, with a master hand. Balakiref stoud for technical immaculacy in actual writing, and for a liberal and eclectic nationalism, Moussorgsky for the elimination of superfluous detail and for an uncompromising realism and a fidelity to Nature that were regarded at that tine as exceedingly daring, Borodin for Oriental colouring and mediæval pageantry, Rimsky-Korsakof for the fantastic and fabular, a vein inspired by his knowledge and love of folklore. Of the four only Borodin permitted any element that can be regarded as a relic of the discarded Italianism to enter into his music, and it must be remembered both that he was quite conscious of the intrusion, and that taken as a whole "Prince Igor" is as Russian as any work of art yet produced in the region of Russian music.

So much for the subject of the expression of heroic nationalism in Music.

When we search for the influence of folklore upon Russian music we find ourselves as it were thrown back now and again from folklore into history. So much of the so-called history is in a way legendary, and so much of folklore is history. The story of "A Life for the Tsar" comes under the category of tales that deserve to be true! IVe cannot say exactly that of the account of Boris Godounof's crime; but we may note that modern historians do not attach much importance to it. The exploits of Ivan the Terrible, of Stenka Razin, and of Pugachof have become folklore, which, indeed, is full of references to figures in Russian history. In Madame Linef's volume on the "Peasant Songs of Great Russia" there is one in which the name of Arakcheief-Alexander I.'s autocratic Minister-occurs, and the song gives the peasant point of view pretty clearly.

"Arakcheief's a gentleman," the song tells us, "and sits alone at table, a glass of rum before him; he drinks up and eats up all our pay. And with this money he has founded factories, built him factories of stone, the windows all in frames, the ceiling all of crystal." I understand that there are already 
references to be found in popular lore to certain episodes in the Russo-Japanese conflict.

There is a department of folklore from which Russian music has acquired a great abundance of inspiration, and that is the supernatural department. No better example of this is to be found than in the operas of Rimsky-Korsakof. In "Sadko" we learn of the translation of the Sea-king's Daughter to earth where she takes the shape of the river Volkhof. In "Sniegourochka" the Snowmaiden floats to Heaven in a vapour at the first touch of the rays from the warm spring sun. In "Christmas Eve Revels" the story of which is also used by Tchaikovsky in "Oxana's Caprice," much trouble is caused through the theft of the moon and stars by his Satanic Majesty. In "Kostchei the Immortal" we meet with a phenomenon to be found in the folklore of other lands. The old ogre's "death" is a separate entity, kept in an obscure hiding-place. When it is found his life ends. In this particular version the "death" is in the tears of his daughter. In Stravinsky's "Firebird," in which Kostchei makes another appearance, the Firebird's egg contains the "death" and the monster is overcome when the egg is broken. In "A Night in May" the Pannochka Russalka, or chief water-nymph, plays the part of good fairy to the hero, aiding him in the discomfiture of his father, the Mayor, who is his rival. In "The Legend of Kitej" the city is saved from an invading enemy by being temporarily submerged at the bottom of a lake. In the "Tale of Tsar Saltan" all sorts of fantastic disasters are visited upon the Emperor's young bride at the instance of a witch, Earbaricha, a member of the Baba Yaga family. Baba Yaga is the subject of an orchestral piece by Lyadof, and makes an appearance in one of Moussorgsky's pictures from his friend Hartmann's exhibition. Another sketch of this un-prepossessing lady occurs in the orchestral suite by Bagrinofsky which you will hear in a moment. We all heard the warning crow of the Golden Cockerel at Drury Lane last year, and no further reference to this example is necessary. All these stories occur frequently in the written and unwritten records of Russian folk-fantasy. IVhatever may be said against the exploitation of nationalism in other countries, I think that even Mr. Ernest Newman will agree with me that there is a pretty good excuse for the Russian attempt to incorporate musical reference to this amazing wzalth of literary material in symphony and opera. [Performance of Bagrinofsky Suite.]

I should like to make a passing allusion to the attempted intimidation of Russian literary authors and musical composers by means of the censor's ban. The history of modern Russian literature is of course punctuated hy instances of censorship, some of them utterly ridiculous. Authors have been obliged to wrap up their protests in a thick garment of allegory, reiniorced 
with metaphorical insertions, and have expended a great deal of ingenuity in the design of this protective costume. Musicians have not altogether escaped the blue pencil. It is a doubleended weapon, and on occasion its other end may cause some personal inconvenience to the writer whose too bold words have been excised. In the reign of the first Nicholas the censors themselves were so bullied by their suspicious superiors that they began to lose nerve and to develop a sort of mania. They searched cookery books, we are told, for insurrectionary ideas. As one sometimes meets with the word "Bombe" in the menu it is permissible to imagine and perhaps to assume that this was considered a just ground for their suspicion. But they went further than that, and not only did the technical terms associated with music become suspect, but they actually exercised a rigid surveillance over music itself, believing, as Professor Pares informs us, that music could be written in a kind of cipher which might conceal its evil intentions from official observation. The committee formed in $185 \mathrm{I}$ to investigate this matter were obliged to admit that the message contained in the music they examined lay too deep for their powers of penetration. We must not forget however that the bell, sounded for the Great Assembly scene in "Ivan the Terrible," was viewed unfavourably, owing presumably to the fact that in Russia the bell is regarded as a sort of symbol of freedom, or rather of the attempt to obtain it, and we know also that "The Golden Cockerel" was censored during the lifetime of its composer. Personally I consider that in its western production the unbridled exploitation of the fantastic element in this opera rather obscured the delicate satire running through it - a satire which was the obvious cause of the censor's uneasiness. I believe I am right in saying that the censor took exception to the appearance of Neptune in Rimsky-Korsakof's opera "Sadko" on the ground that a pagan god could not be tolerated. Those who are acquainted with Russian methods of Press censorship will not be astonished at these apparently peculiar alarums and excursions. It is sufficient for our purpose to remark that music shares with literature the honour of being considered a medium through which social reform may be promulgated.

An early and rather strange instance of the connection between Russian fiction and the modern Russian school of Music is Moussorgsky's "Impromptu passioné" for pianoforte. It was begun in a moment of exaltation engendered by reading Herzen's famous novel "Who is to blame?" which attacks the institution of Marriage. I do not think this piece has ever been published. Stassof, who saw the manuscript, was quite unimpressed by it. There does not appear to be any parallel instance ; but one of the most famous Russian novels illustrates a reversal of the 
process. In Tolstoi's "Kreutzer Sonata" we find all sorts of evil influences attributed to Music. But Tolstoi's opinions on the art must be reserved for a little while.

I wish first to draw attention to the extent to which Russian fiction has contributed the actual literary substance of Russian music. Pushkin comes again to the fore. We need only mention once again his prose tales, "The Captain's Daughter," "Doubrovsky," "The Queen of Spades" and the novel in verse, "Evgenie Oniegin"-each set in operatic form by Cui, Napravnik, and Tchaikovsky respectively - to obtain an idea of what he has done for Russian composers. Needless to say, there are few composers who have neglected him when applying themselves to song. 'There are some fifteen operas, all well known, which are either adaptations or direct settings of Pushkin material in Cheshikin's index, and neither "The Golden Cockerel" nor Rakhmaninof's "Avaricious Knight" is mentioned.

Gogol has also been the source of a good deal of inspiration. I have referred to his stories of the Ukrain and the operas "Christmas Eve Revels," its Tchaikovskian variant, "Oxana's Caprice," and "A Night in May," which have sprung from them. Moussorgsky took this author's comedy "The Matchmaker" for his abortive essay in the declamatory operatic style. $\mathrm{He}$ also set "The Fair at Sorotchinsk," which likewise was left unfinished. "Taras Bulba" has been employed by more than one composer.

Ostrovsky, who has something in common with Gogol as a dramatic writer, has been resorted to by Tchaikovsky and Blaramberg for "The Voyevode," by Tchaikovsky and Kashperof for "The Storm," by Serof for "The Power of Evil," and by Rimsky-Korsakof and Grechaninof for "The Snowmaiden," in which the dramatist had suddenly given up the lampooning of Moscow bourgeois society, his accustomed medium, and made an entirely successful invasion of Fairyland.

A miscellaneous survey reveals that the texts of four of Rubinstein's operas are taken from the works of Lermontof, and that Rimsky-Korsakof has gone to Mey for his two historical contributions, "Ivan the Terrible " and "Servilia." Coming to a later period Dostoievsky's "Christmas Tree" is the part-basis of an opera by Rebikof, Korolenko's "Murmuring Forest" has been adopted by the same composer, and Turgenef's "Assya" has been put into operatic form by Ippolitof-Ivanof. The rising generation is still fairly faithful to native literature. Stravinsky has done some songs of Balmont, a quite modern poet whose boast it is that it was he who first discovered the music of the Russian language. Such conceits as the following: "Poets prior to me are mere precursors" remind us of an English playwright who has favoured this Association with his views but is in no need of further advertisement. Such a complete eclectic as Balmont, 
who has already translated the works of Verlaine, Ibsen, Hauptmann, Poë, Shelley, Maeterlinck, Calderon, and Whitman, probably knows the gentleman as well as we. Another pcet, much read in Russia just now, is the wife of Merejkovsky, known by her maiden name of Hippius when writing verse and as Anton Krainy when signing criticism. She has found a musical advocate in Miaskovsky, who has set three little poems, "Conflict," "Uniformity," and "Circles," quite imaginatively.

Seeing that contemporary Russian poets are striving to endow their verse with an intensely musical quality, it does not seem likely that musicians will now begin to hold aloof from the work of their compatriots.

There is one more branch of my subject : the appearance of music in Russian Literature. This I must subdivide into its two diverging offshoots. The first I shall call the episodic appearance. Music as an episode in fiction has not been a great success. Most novelists have committed some horrible blunder or other. Among the Russians Turgenef has been guilty of one or two "howlers" which come a little unexpectedly from a man whose greatest friend was a musician-Madame Viardot, I mean. In his "House of Gentlefolk" we have a rather important example of the episodic treatment of music. One of its principal characters, Lemm, is a German musician, "A devoted admirer of Bach and Handel, a master of his art, gifted with a lively imagination and that boldness of conception which is only vouchsafed to the German race." This may still apply, perhaps, to matters outside music, but the only boldness noticeable to-day in German music is that which consists in repeating commonplaces with a loudness that increases at each repetition. Turgenef at that time had apparently no great opinion of Russian music. Later, in his "Fathers and Children," he seems to have been aware of what was going on in the musical world around him, and we are informed in this novel that Arkady Nikolaevich had views regarding the significance of national melodies. At the end of the volume Turgenef speaks of the number of Russian students engaged in the study of chemistry at Heidelberg, and makes us think of Borodin; the composer of "Prince Igor" cannot, however, have been among the "two or three such young chemists, who don't know oxygen from nitrogen, but are filled with scepticism and self-conceit. . .." We are reminded of Borodin also by the circumstances that this composer was called a "musical Nihilist" by some of his critics. It was out of the mouth of Bazarof, the hero of "Fathers and Children," that the term first came. In "Smoke" Turgenef waxes sarcastic at the expense of Russian art. Questioned as to his opinion of Glinka, Potugin replies: "If we'd said, for example, that Glinka was really a remarkable musician, who was only prevented by 
circumstances-outer and inner-from becoming the founder of the Russian opera, none would have disputed it ; but no, that was too much to expect! They must at once raise him to the dignity of commander-in-chief, of grand-marshal, in the musical world, and disparage other nations while they were about it. ..." In "Rudin" there are several instances of Turgenef's fondness for the introduction of musieal episodes. Pandalevsky, one of the principal characters, gives a drawing-room performance of an Etude of Thalberg, which he played "fairly well." This strikes a new note. Musical performances in novels are, I think, without exception, carried out in a fashion that exhausts the novelist's power of eulogy. Pandalevsky creates a more favourable impression on another occasion with Schubert's Erl-Koenig. There is a passage in the epilogue of this book which rather startles us. "'Let us clink glasses, Dmitri, and sing as of old, Gaudeamus igitur.' The friends clinked their glasses and sang the old student song in strained voices, all out of tune, in the true Russian style." Had the author attributed the faulty intonation and defective production to the contents of the glasses we should have been less astonished. It is in this novel, by the way, that Turgenef appears to commit himself to a nationalistic opinion. "Cosmopolitanism," he says, "is all twaddle, the cosmopolitan is a nonentity; without nationality is no art, nor truth, nor life, nor anything." In "Smoke" Turgenef again introduces the critical element of cold water. The lively Bambaef was "thrown into special raptures over the thought of Russian music" whilst on a visit to Baden, a favourite foreign resort of his countrymen, and in his enthusiasm begins to hum a song of Varlarmof's. He is interrupted by the assembled company, who inform him that he has all unconsciously changed his tune-that he is in fact singing the "Miserere" from "Trovatore," and singing it excruciatingly. Better musicians than Bambaef had mistaken Italian music for Russian-music of their own composition. I shall have more to say of Turgenef when treating of the thematic appearance of music in literature.

Tolstoi's "Kreutyer Sonata" comes, I think, properly under the heading of episodic. We are most of us obliged to disagree with the great novelist. We do not think that Beethoven was the author of Pozdnischef's matrimonial misfortunes. We musicians find it somewhat difficult to follow him in his estimate of the first movement of the Sonata. Let us bear in mind nowever that its emotional significance must have been much more intense when Tolstoi first heard the work than it now is to us. Tolstoi's views on music and on art in general are of course notoriously strange. Mr. Bellaigue expresses a wonderment, shared by many, that the works of Beethoven, the chastest of all composers, should have been singled out as an example of 
music that wields an unhealthy influence. Mr. Romain Rolland solves the problem by saying that it was because Beethoven was the most powerful of all composers. And there is a phenomenon which I think escapes the notice of most of us musicians, and that is the circumstance that music effects those inexperienced in music quite differently. What makes us weep makes them laugh, and vice versa. Thus to choose a powerful composer seems rather like playing a pretty safe card.

'Tolstoi, although he expressed the opinion that Music ought to be under State control, was not altogether unsympathetic towards it. In "Family Happiness," for instance, "the whole cycle of love from springtime to autumn is unrolled (the words are Mr. Rolland's) to the phrases of the Sonata quasi una Fantasia." Nekhludof is moved nearly to tears by the Andante of the Fifth Symphony in "Resurrection." "War and Peace" has many such musical episodes. There is some interesting information to be gathered from the "Life and Letters of Tchaikovsky." Towards the close of 1876 Tolstoi visited Moscow. At Tchaikovsky's suggestion Nicholas Rubinstein, the principal of the Conservatoire, arranged a musical evening in Tolstoi's honour. "Never in the whole course of my life," wrote Tchaikovsky in his diary, "did I feel so flattered, never so proud of my creative power, as when Leo Tolstoi, sitting by my side, listened to my Andante (from the D major Quartet) while the tears streamed down his face." Shortly after this the novelist wrote to the composer advising him of the despatch of some Folk-songs he had been perusing. He implores Tchaikovsky "for God's sake" to treat them in the Mozart-Haydn style and not after the BetthovenSchumann-Berlioz school, which only strives for the sensational. 'The composer's respect for the author underwent a rapid diminution as may be seen by anyone caring to reopen the volume. I can only quote one further letter - that in which Tchaikovsky, during an epistolary discussion with his patroness ron Meck on the subject of Opera as an art-form, tells her that Tolstoi had advised him to give up his pursuit of theatrical success, and reminds her that in "War and Peace" the heroine favours the reader with her views on the conventionalised operatic absurdities.

On Wagner Tolstoi pronounced judgnent after a single hearing of a portion ot "Siegfried." He arrived after it had begun and was with difficulty persuaded to remain until the middle of Act II. His verdict was that Wagner could nut be expected to write anything that was not evil.

One or two other novelists have given us occasional music. In Dostoievsky's "House of the Dead" we have a performance by the prison orchestra, and are told that the most capable instrumentalist is the gentleman who has killed his father. From 
this it is pardonable to assume that Christie Mahon, the hero of "The Playboy of the Western World," might have been a successful parricide, and thus perhaps a musician, if only his arm had been stronger!

In the same author's "The Brothers Karamazof" he puts a vile pun into the mouth of Karamazof pere. As it is a musical pun it may be regarded as concerning us. Feodor Pavlovich recounts how in inviting a Captain of Police to dine he addressed him as follows :-- "Mr. Ispravnik,' said I, 'be our Napravnik."” Napravnik the conductor has already been mentioned as the composer of an opera based on Pushkin's "Doubrovsky." The joke fell fiat, and Karamazof had to explain that he wanted the policeman on his side in a certain undertaking in which a general social harmony was requisite. Napravnik, he explains, "is our well-known Russian orchestra conductor...." It is not clear from the translation whether the word Russian qualifies "orchestra" or "conductor." Napravnik is by birth a Bohemian.

In considering Music as the theme of Russian Fiction we have to return to Turgenef. Clara Milich, the heroine of one of his "Dream Tales," is spoken of as possessing a talent of the first rank. The hero is first told of her by one of bis friends, who cannot make out, he says, whether she is to be a Rachel or a Viardot, for she sings exquisitely and recites and plays as well. She is heard by the hero at a literary and musical matinée in a large private drawing-room. She sings ballads by Glinka and Tchaikovsky, and then gives an exhibition of her histrionic prowess by reciting Tatiana's letter from "Evgenie Oniegin." There are some amusing references to other performers such as the flute-player who "dribbled away at a piece of consumptive tendency."

Another story from the same series purports to originate in an old Italian manuscript. It is called "The Song of Triumphant Love," and tells of two young men, Fabio and Muzzio, who were of the same age, of near kinship and of similar tastes in love. Muzzio was a musician, Fabio a painter. They were both devoted to one Valeria. The painter is the victor. Muzzio disappears for five years and returns from the Far East with an Indian violin, "like those of to-day," the author describes it, but with only three strings; the upper part was covered with a bluish snake-skin and the reed bow was half-moon shape, and on its extreme end glittered a pointed diamond. On' this extraordinary instrument Muzzio plays a melody from Ceylon. It is the Song of Triumphant Love. How the song triumphs even after its singer has been stabbed to death by the jealous husband you may learn by reading Mrs. (jarnett's translation of the story.

- The subject of operatic works by Harteveldt and Simon. 
One of the quotations I have made from the writings of Turgenet prompts $m e$ to read you an extract from Mrs. Newmarch's volume "The Russian Opera." She bas two stories to tell of Vladimir Stassof, one of which illustrates the Russian weakness for hot and often futile discussion. Stassof had been arguing with Turgenef, "whose cosmopolitan and rather supercilious attitude towards the art of young Russia infuriated the champion of nationalism. At last, Turgenef, wearied, perhaps, with what he called 'this chewing of dried grass,' and suffering acutely from rheumatic gout, showed signs of yielding to Stassof's onslaugbts. 'There!' cried the latter triumphantly, 'now I see you agree with me!' This acted like the dart planted in the hide of the weary or reluctant bull. Turgenef sprang from his chair and shuffled on his bandaged feet to the window, exclaiming: "Agree with you, indeed! If I felt I was beginning to think like you, I should fing open the window [bere he suited the action to the word] and scream to the passers-by, "Take me to a lunatic asylum! I agree with Stassof !'”

I have a vague recollection of having read an account, supposed to have been written by someone we may describe as a very unofficial critic, of a performance by Anton Rubinstein. It is couched in the homeliest of language. It replaces the customary jargon of criticism with something quite different. I expect it is known to you. Gorbounof's sketch "La Traviata," as described by a shopkeeper, is in the same vein. Slyeptzof has done a story called "The Choir l'ractice." His choir practice would have been better suited as a preparation for worship in the temple of Bacchus. During frequent pauses the singers resort to vodka. "By the time the second pint of spirit was finished they had arrived at the stage of walking unceremoniously up and down the room. . . . The choir master, holding the deacon by his coat-button, assured him for the tenth time (a propos of nothing) that his wife was an angel, and that but for her he should have come to utter ruin. The conversation then jumped with extraordinary rapidity back to music, and the deacon affirmed that $\mathrm{C}$ sharp major and $\mathrm{G}$ minor are the same, and that 'the whole thing depends upon how you breathe,' and finally proved to demonstration that all these composers ought long ago to have been kicked down stairs.' Notwithstanding all this the choirmaster once more went into the ante-room, waked Petia, and sent him for a third pint." It is not very astonishing that people who can no longer distinguish between two such diflerent keys should confuse sacred and secular music; the practice ends with a wild performance of some popular songs. This is how the story concludes: "At about eleven o'clock at night the deacon was hunting for his goloshes in the ante-room. For a long time he could not find them; at last he stuck his 
foot into somebody's cap, which happened to be lying on the floor, and went home."

Saltikof, the great satirist, wrote a story called "The Eagle as Maecenas," which is of interest to us although it does not deal specifically with music, but with Art in general. It is a satire upon a certain attempt to introduce culture into Society, a brand of culture that is selected with a view to satisfying the needs of the reigning monarch. Having, at the suggestion of the Eagle, organised Forest Society in a fashion calculated to favour the interests of the landed proprietor, and having got the whole arrangement into working order, the authorities suddenly bethought themselves that "in all high-class establishments Science and Art are supposed to be represented." By this omission we are told the robin, the woodpecker, and the nightingale were particularly aggrieved. So on the next day the "Golden Age" began in the Eagle's establishment. The stirlings set to work to learn by heart the hymn "Let our youth be fed with science"; the corncrakes and nudsuckers began practising the trumpet; the parrots invented new tricks ... . Last, but not least, the oldest patriarch among the starlings was appointed poet-laureate, with the honorary title of "Vasili Kirilych Trediakovsky" ... . The inevitable "Tournament of Arts" provides Saltikof with a splendid opportunity for biting satire. It is not very difficult to read between the lines of this: "Then the nightingale began his song, and made a mess of it from the rery first note He sang of the joy of the flunkey hearing that (iod has sent him a master; he sang of the magnanimity of Eagles, and of their liberality in tipping flunkeys ... . But however desperately he tried to pitch his voict in the true flunkey tone, the art that dwelt within his breast somehow or other would not be controlled .... and kept on bursting forth in spite of all his ellorts."

We find very tew references to contemporary musical life in Russian fiction, but Saltikof is responsible for one which ought to please a section of the audience present at my last year's lecture on Moussorgsky. "We had then a brief Discussion upon the vexed question of "programme music" in general and Moussorgsky's in particular. The power of exact description attributed to music by Moussorgsky was called into question. Saltikof was also inclined to disagree with the composer's method, and with him to disagree was to satirise. Balakiref in one of his letters to Calvocoressi relates that in a clever article on the subject Saltikof suggested the musical illustration of the following picture: A dark and freezing November day in Petrograd. A cab-horse half dead with hunger is pulling along painfully a sadfaced fare. Suddenly the vehicle stops $(\neg)$; the cabby gets down from the box to pick up his fallen whip...."-and so forth. 
As a conclusion to this, my final heading, 1 may draw your attention to two novels. One is perhaps better described as a short story, of which the subject is purely musical. It is called "The Blind Musician," and is by Vladimir Korolenko, whose work was the theme of a lecture given some years ago at the London Institute by the then English lecturer at Petrograd University. Korolenko is now well known as a publicist as well as a literary man. The blind musician is a flute-player. In the book there is a passage in which someone tries to explain to the afflicted youth the affinity between sound and colour. This was written in the early 'eighties. Is it too fanciful to suggest that Scryabin may have been influenced by this conversation?

The second story is by another author of Little-Russian origin, by name Potapenko. Entitled "The Curse of Talent," it is the short life-history of a poor little prodigy violinist who is exploited by his tather. Tired to death and tortured by ceaseless practising on the instrument which has been the means of depriving him of all childish enjoyments, he falls asleep and has a fearful nightmare, in which he sees an enormous fiddle, with a head like a tiger's, approaching him and endeavouring to devour him. Then his own instrument becomes part of him, and his master putting the bow into his hand tells him that as he and his fiddle are now inseparable he can now devote himself to playing the livelong day. $\mathrm{He}$ is taken to a concert, but rather than gratify his audience, he tears away the violin and part of his chest with it. No one notices that he is bleeding to death; his father and his master are disputing the claim of having produced the prodigy. Waking from this awful dream the first object he perceives is the dreaded violin on which he is in reality to perform that evening. The performance does not, however, take place, for little Mitia has hanged himself with his belt.

I think I have now proved to you how very closely Russian Literature and Russian Music have been bound up in the past. 1 have shown that Music has performed the function of popularising history and of beautifying folklore. The connection between Fiction and Music is, as you have seen, fairly close, and students of contemporary music, literature and painting, will know that at this moment the three arts are taking a cornmon direction. They are all striving for progress. In Music, Literature, Painting and indeed in Sculpture as well, the eyes of the Western World are turned towards the Slavs. Stravinsky, Scryabin, Prokofief, and Miaskovsky may, I think, be considered as representing Music; Balmont, Valery Briussof, and Blok are the foremost Poets ; Anrep, Bilibin, Pereplochikof, Roerich and Bakst uphold the best traditions of Painting ; Andreief, Gorky and Sologoub are notable contributors to native I) rama (the last-named has discinguished himself in Fiction and Poetry as well); Biely and Hippius on the one hand and 
Andreief, Artsibashef and Gorky on the other are the Russian novelists of the day; Merejkovsky stands for literary criticism and exegesis; and if we cannot point to any great sculptor in Russia itself since the death of Antokolsky, to whom Glazounof has dedicated a Cantata, we shall shortly have an opportunity of seaing in the work of the Serbian Meshtrovich that Slav sculpture leads the way. Examine the works of these and you will observe that there is still a common inspiration which may be considered as binding them together. Of Russian Literature and Russian Music we may safely predict at any rate that they are likely to remain national; that they will preserve, that is, a quality rendering them distinct from the art-manifestations of other lands for some little time to come.

\section{DISCUSSION}

The Chairman : I understood the lecturer to say that the last four words of the title as printed on the synopsis card-Russian literature and Russian music "as expressions of nationalism"were intended in reality only to be the first item of his detailed synopsis. However that may be, I think that nationalism is necessarily at the bottom of the whole Russian musical question. In May, 1913, 1 had the pleasure of giving a lecture-recital on Rubinstein before this Association, and all my remarks took this as a postulate. Four general reflections present themselves about Russia. First there is its vast size ; it extends North and South from the Arctic regions to the Tropics; in width it runs exactly half round the world; it occupies one-sixth of the land surface of the globe; its population is one-tenth of the whole population of the globe. Secondly, nine-tenths of this population are Slavs, a race with great potentialities which is only just beginning to be conscious of its strength. Thirdly, the social tabric is based entirely on the village-community system, a thing which we have outgrown in the IVest, but which is still the ruling factor in most countries of the East; a large part of my own life was spent in an Eastern country other than Russia, where official duty was in direct contact with the villagecommunity system at every hour of the day, and where it became second nature to reckon with its characteristics. Fourthly, since 
the Russo-Japanese War of ten years' back, the superior governmental machinery of Russia has tended more and more to become democratised. A blend of all these reflections gives the true background against which Russia's recent surprising musical development should be considered. I might draw attention to the fulness of matter in the lecture and say how well written it is; but as to that you can judge for yourselves. That was an interesting work which Mr. Parlovitz rendered. Moussorgsky's Suite on Exhibition Pictures, which he played here last year, has been orchestrated by Sir Henry Wood, as you perhaps know, and was played on the orchestra at Queen's Hall last Saturday. The lecturer sfoke about references to music appearing in Russian novels, \&c. Dr. Southgate lectured on a similar subject for this country about twenty years back, and if he has any remarks to make on the present matter I am sure that we should be very glad to hear then.

Dr. Southgate: The subject of my Paper was "The Maltreatment of Music by Novelists." I think, if I remember rightly, in that paper I said something about Tolstoy and the "Kreutzer Sonata." I-would like to ask the lecturer one question : He has told us of Operas built upon national subjects, and I would ask him whether also the Russian composers have produced any other operas founded not on national subjects. but on themes which may have been taken from other countries, or subjects which cannot be described as entirely national. It would be interesting to know whether the composers in their treatment of music have looked beyond the confines of their own country.

Mr. Montagu-Nathan: I think that the most effective reply to the question put by Dr. Southgate is to recall that in the book which I quoted-Cheshikin's History of Russian Opera-there are two indexes, one of them devoted to operas built upon subjects by native authors, and the other giving the names of operas of which the texts have a foreign origin. The majority of Rubinstein's subjects were non-Russian. Another example of an opera miscalled "Russian" is the work announced for performance at the London Opera House, called "Mlle. Fif," based upon a short story by Guy de Maupassant and set to music by César Cui. There is no excuse for giving this as a specimen of Russian music ; the only excuse for giving it at all is that "Mlle. Fif " contains a reminder that the brutality of the Prussian officer was amply proven in $187 \mathrm{r}$.

A Vote of Thanks to the lecturer was carried by acclamation. 